International Journal of Social Sciences and Humanities
Available online at www.sciencescholar.us
Vol. 5 No. 2, August 2021, pages: 79-91
e-ISSN: 2550-7001, p-ISSN: 2550-701X
https://doi.org/10.29332/ijssh.v5n2.1167

\title{
Relevance of Human Resource Management on Small Business Objective in Digital Era: A Critical Review of Research Evidence
}

CrossMark

Abdul Samad Arief a, Petrus Jacob Pattiasina ${ }^{b}$, Sahat Parulian Remus ${ }^{\mathrm{c}}$

Manuscript submitted: 27 March 2021, Manuscript revised: 09 April 2021, Accepted for publication: 18 May 2021

Corresponding Author ${ }^{\text {a }}$

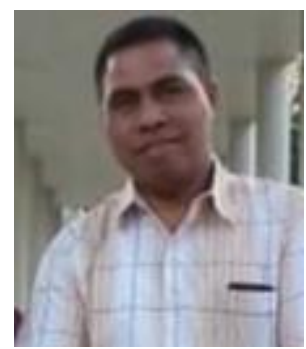

Keywords

HR governance;

objectives and efforts

relevance;

objectives of SMES;

review studies;

\begin{abstract}
One of the essential elements in advancing small and medium enterprises is the availability of Human Resources management. So HR development must be relevant to the needs of small businesses, especially now that small businesses are present in the digital era. So to see the suitability of HR development with the needs of small businesses in achieving their core goals. So we have reviewed dozens of papers on our efforts to find this relevance through reviewing the papers we search electronically on Google scholar-based data. We specialize in papers published between 2010 and 2021, so we can get the latest data. To get answers to this research question, we analyzed the data using a phenomenological approach. We also involve the coding, interpretation, and evaluation system to find accurate, valid, and reliable data findings. So the results include that there is a close relationship between the SDm system and the central ideals of SMEs. Logically, if the human resources are good, the company and the smallest business will quickly improve and efficiently achieve the final goal.
\end{abstract}

International Journal of Social Sciences and Humanities (C) 2021. This is an open access article under the CC BY-NC-ND license (https://creativecommons.org/licenses/by-nc-nd/4.0/).

\section{Contents}

Abstract

1 Introduction

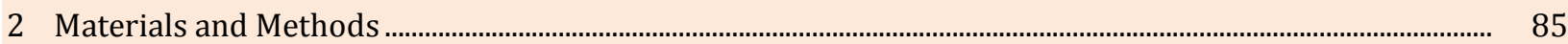

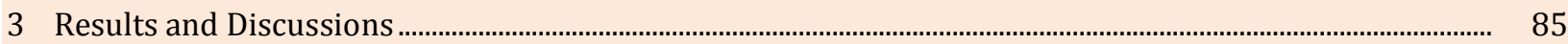

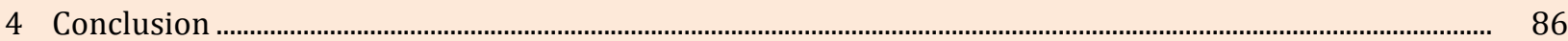

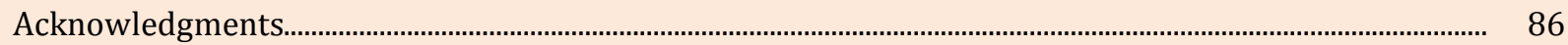

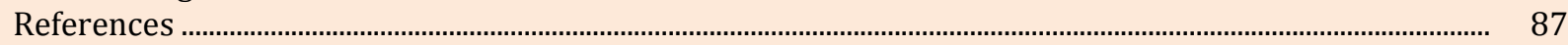

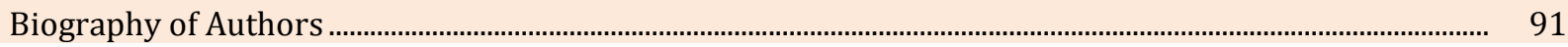

a Universitas Fajar, Indonesia

${ }^{\mathrm{b}}$ Universitas Pattimura, Indonesia

c Universitas Methodist Indonesia 


\section{Introduction}

Small and medium enterprises (SMEs) will not be able to operate effectively without having superior human resources (HR) (Nurani et al., 2021; Sudarmo et al., 2021). The SMEs owners themselves carry out all aspects, sometimes with the help of friends and family. However, if a company employs more than 25 employees, it is required to have a company regulation legalized by the Ministry of Manpower and Transmigration. In such conditions, the company must have trained workers. They are workers who have expertise in a particular field that is obtained through work experience. In other words, they are trained human resources (Sedyastuti et al., 2021). If the workforce is not educated and untrained, they are not trained in specific fields or have no expertise in any field. In this condition, the writer responds to a question about the role of SME owners in recruiting employees in a company of this size. Company owners have started to think about employee salaries, health insurance, employee income tax, and others related to employee rights and obligations by existing regulations. Uneducated and untrained labor is manual labor that only relies on labor. Examples of this model workforce are coolies, transport workers, factory workers, servants, pedicab drivers, and domestic workers / from families who only need any skills. On that basis, this study wants to find evidence from previous studies of how superior human resources are related to the final goals of SMEs both in the context of business in Indonesia and elsewhere (Nurani et al., 2020).

SMEs are the spearhead of a nation's economy that needs the attention of the state and business leaders. Because this small business has experienced tremendous growth even in the pandemic era (Ellis, 2010). Indonesia, for example, has a significant share in the financial turnover of society. This can be seen from its commitment to Gross Domestic Product. Indonesia's GDP has continued to increase without fail this year. The development of SMEs in Indonesia is extensive, with a large number of businesses being opened. The economy is ready to open new openings for 9.6 million individuals, while large organizations can give birth to new openings Caliendo \& Kritikos (2010).

The reason is that Indonesia is a country that has a population of more than 260 million people today. Economically with a large population, SMEs have a significant role in the growth and development of an economy with an annual growth rate of almost double digits (Randolph et al., 2019; Del Brìo \& Junquera, 2003; Wisenthige \& Guoping, 2016). Inflation is at its lowest level from year to year. Inflation has reached the highest level since the 1990s, with $20 \%$ in the first quarter of this year, and in the second quarter of this year, $10.3 \%$. The economy has recorded a growth of 19.9 percent in the last two years and is projected to grow by 14.2 percent in 2014. However, with the high adoption of SMEs, the downward trend in the economy can be adjusted to the country's aspirations (Yacob et al., 2019).

Currently, it is estimated that 1.3 million new small business units have to be developed in Indonesia every year, even though the infrastructure to make it happen is relatively very limited (Thaha, 2020). Other data shows that Indonesia needs 20 million new businesses outside the agricultural sector. Along with the increasing use of technology for supporting small businesses. This is considering that approximately 60 percent of the production process is still simply employing simple technology. The quality of SME human resources is needed, especially in the fields of skills and knowledge. Human resources (HR) development must be supported in various aspects (Riniwati, 2016).

According to Apriyani (2014), the level of education in Indonesia is 44.1 percent, D-3 (7.4 percent), and S-1 (17.9 percent), and the rest are below high school; this is an unbalanced reality. So if it correlates with the need for human resources in small businesses, then the education of SMEs at the national level is relatively low, especially among young people. The government hopes that the growth of this people's business industry will continue to increase incomes and wealth in the country, and the development of this business industry must be able to survive even in a crisis era. The economy will grow faster than any other industry and will need to expand at a rate of 1.5 percent a year to keep pace with growth in the size of the economy. This business needs more workers with good HR, and they need to employ more workers who are ready to work to meet the demand for HR products and services and compete with other industries both at home and abroad (Wulansari et al., 2015).

The industry will have to increase the number of employees. Human Resource Competency Development must be considered. SMEs must be able to create an entrepreneurial workforce that can compete openly in the global market. The development of small businesses cannot be separated from the role of cooperative institutions in raw material procurement and marketing of SME products. The implementation of HR 
Competency development needs concrete data about how the profile was created. The current SME and HR competencies and their effect on performance. The government is increasingly developing small and medium enterprises. 678,415 SME units in Indonesia contribute $23.27 \%$ to gross domestic product (Charoenrat \& Harvie, 2014; Wang et al., 2016; Yang et al., 2017). The critical role of systems in the company is to support business and operational processes.

The company's strategy will build on the problems to be built to develop the company's business strategy and strategy. Company strategy can be seen in production, financial and accounting information, human resources, marketing, employee and manager development, and various strategies to make the company a better place (Toby \& Peterside, 2014). The development of a company plays an essential role in the economy in Indonesia, especially in the performance of this sector. Economic growth is driven by the growth of small and medium enterprises in the region and the need to attract and retain workers. According to a study by the World Bank's United Nations, the country's economy is one of the fastest-growing economies in the world in the past three years. The city's economy is expected to grow by $7.8 \%$ in 2014, up from $6.4 \%$ in 2013.

The city's economy grew by $7.2 \%$ in the first quarter of 2014 (Reed \& Mberu, 2014). According to Apriyani (2014), the level of education in Indonesia is 44.1 percent, D-3 (7.4 percent), and S-1 (17.9 percent), and the rest are below high school; this is an unbalanced reality. So if it correlates with the need for human resources in small businesses, then the education of SMEs at the national level is relatively low, especially among young people. The government hopes that the growth of this people's business industry will continue to increase incomes and wealth in the country, and the development of this business industry must be able to survive even in a crisis era. The economy will grow faster than any other industry and will need to expand at a rate of 1.5 percent a year to keep pace with growth in the size of the economy. This business needs more workers with good HR, and they need to employ more workers who are ready to work to meet the demand for HR products and services and compete with other industries both at home and abroad (Wulansari et al., 2015).

The population of Indonesia is the highest in this country with a small business profession for the first time since 2007. With the help of information systems, human resources are used to obtain, manipulate, analyze, retrieve and distribute information. Human labor is computer hardware and software and includes people, forms, policies, and data. The development of information technology to meet the information needs of human resources encourages the creation of human resource information systems. In general, the benefits of using resource information systems include: It allows organizations to support activities and increase the speed of information transactions. The company's ability to utilize the potential of information system resources depends on the organization's size, the support, and commitment of top management, the philosophy of the company's human resources, employee involvement, and employee motivation to adopt change (Riniwati, 2016). Information systems can be used to streamline and increase the efficiency and effectiveness of administrative functions. It can also help improve employee satisfaction by providing accurate and real-time human resource services.

\section{Literature}

Their essential nature determines the theoretical review of competencies or abilities. Someone associated with work effectively or very successfully was essential Suharti et al., (2013). Competency limitations or specific competencies for a job are patterns or guidelines in selecting employees. Competency motives can be in the form of competency factors or a person's ability to carry out a job well. The level of competence can be developed through education and training. The ability to teach well is how the lecturer can teach well; teaching is easy to understand, and the analysis is sharp. Knowledge about abilities and knowledge can be developed through education, training, and analysis. Teaching ability is the primary teaching ability, meaning at the threshold level of competence and teaching ability (From, 2017). A teacher's competence is how well he can educate a child to be a good teacher. A person's ability can be shown, for example, how well they teach children to read and understand a story. A child's education can be demonstrated by good teaching and a good enough understanding so that it can be distinguished from the abilities of others (Nicholls, 2017; Schunk, 2012).

HR improvement training can be seen as having good potential on the job and can effectively assess its effectiveness and achieve the ultimate goal of SMEs. Training a staff person to be good at a job is made possible by demonstrating good skills and understanding teaching styles and teaching techniques. It can be

Arief, A. S., Pattiasina, P. J., \& Remus, S. P. (2021). Relevance of human resource management on small business objective in digital era: A critical review of research evidence. International Journal of Social Sciences and

Humanities, 5(2), 79-91. https://doi.org/10.29332/ijssh.v5n2.1167 
challenging to teach someone to be effective in a job that is difficult to teach. Hidden competencies in the form of skills that may be more valuable. Ardiana et al. (2010), identify three basic skills: technical skills, human abilities, and human abilities. Analysis of the competence of SME HR is intended to produce a profile or model for individual performance management, career development, management, and leadership. The skills needed to achieve success can be obtained by understanding the traits we look for in people working in this organization and understanding how the different parts of the organization work together (Widiastuti \& Martini, 2016).

The essence of an individual can be used to demonstrate how to improve the efficiency of company human capital by evaluating expertise, education, particular skills required, education and training, and experience. (Yusuf \& Al Arif, 2015). Assessing the unique skills and preparation available, the ability to integrate and organize all of an organization's interests and events, and to view the organization as a whole, and how many levels of turbulence are mutually contradictory and knowable can all be used to demonstrate the ability to schedule and monitor. It is used in HR management philosophy to evaluate employers' productivity in the workplace and the willingness of employees to collaborate with coworkers (Samsuni, 2017; Hutagaluh \& Aslan, 2019; Hutagaluh et al., 2020; Hifza et al., 2020). HR hypothesis is founded on an interpretation of the evidence and experience, expertise, and attitudes used to do well at work. He also evaluates its success in terms of how it reacts to external and internal factors, such as its performance and climate. HR theory is used to assess the performance of individuals in an organization, either personally or collectively. In Indonesia, a treasury network analysis was used to define the differentiating aspects of SMEs' results (Komalasari et al., 2019).

\section{Performance in SMEs}

The job or accomplishment of an individual or group of people working to advance the company is referred to as HR success for SMEs. The following equation can be used to express performance empirically: $f=$ performance (A x E x S) - a stands for capacity, E for effort, and $S$ for support. Factor (A) is an innate desire to choose the best person for the role and have a genuine interest in it. Individual productivity components can be seen in productivity from three different perspectives: productivity, output, and operation. Individual elements of success can be used in workplace performance as well. Setting business performance goals is an excellent place to start when determining employee performance. The work is formally described in the job description, with requirements and tasks included in the job design. The production is the product of a job being completed, which can then be directly expressed in the results of SMEs (Dharmanegara et al., 2016).

HR work success for SMEs can be defined as achieving work outcomes following the rules and standards applicable to all work organizations in general. The term 'performance' is sometimes used to describe a person's or a group's performance at work. It can also be used to classify groups or teamwork teams, which can be challenging to do consistently with the essence of the work and the amount of production generated in a given amount of time. Demonstrate the maximum effect of a shift in results; it is often used to describe results about the whole job community or work unit, rather than just one individual or group of staff in one workplace. a team or a job unit Person and teamwork performance, as well as collective performance in a single task and the performance of workgroups against each other, are all examples of 'job performance. This is also used to describe the impact of shifts in performance on the workforce. Everyone is supposed to do something that is expected of him by someone or a computer, according to Kooij et al., (2013). Understanding success will help us get a better understanding of how we interpret it. A collection of outcomes is referred to as performance, and it refers to a person's or group's results or level of achievement. The HR group performs a series of totals and totals, groups and companies, groups, companies, groups, and companies (Kehoe \& Wright, 2013).

Schools, hospitals, corporations, banks, colleges, and other public institutions, for example, need human capital that is willing to work to help organizations meet their central goals. HR success may also be described as something that one may anticipate happening to themselves or others. The term "success" can refer to anything from an act of achievement to the performance of individuals and objects, as well as something that has been done or will be accomplished soon. The word "performers" refers to those who have attained or are predicted to achieve a certain level of performance in a particular field or for a certain period (Noe et al., 2017). The term "performances" may also refer to the outcomes or desires of individuals or things that have 
been done in the past or will be achieved in the future. This refers to "having" or "doing" positively or negatively.

An individual or a group of people can put in the effort to perfect something. Success is a link in this relationship because the individual can do something or lead a group of people. The term 'success' refers to a person's willingness or ability to attain a target or an achieved goal, as well as the ability to be inspired or driven to achieve goals or aims that are outside of the person's skills, such as the drive or inspiration to work with good in a job or become an expert in a job. It may also refer to a person's motivation or ability to accomplish goals or objectives and the desire to be successful at something outside of one's skills or abilities. It may also refer to a person's motivation or ability to attain goals or objectives (Bratton \& Gold, 2017).

The authors refer to questions about small business success and the role of management in enhancing it based on the evidence of research evidence described above (Glaub et al., 2014). He mentions an Indonesian survey of small and medium enterprises (SMEs) that looked at management activities and the efficiency of human capital operated by small companies. According to the report, $60 \%$ of small business owners do use conventional technologies, which can be accomplished with insufficient resources, technology, and poor management; most Italian companies are unable to satisfy bank requirements; and there is a high reliance on government facilities and a shortage of access to capital sources (Robb \& Robinson, 2014).

\section{Micro-Enterprise}

Small and medium enterprises are viable businesses run by individuals and small business associations that meet the concept of micro-enterprises set out by the law (Wijaksono et al., 2014). Microbusinesses have several characteristics; for example, the categories of company products/services are not necessarily set and can vary at any time. Home businesses, individual cultivators, breeders, fishermen, and cultivators; food and beverage industry, wood and rattan processing furniture industry, blacksmith tool manufacturing industry; trading businesses such as street vendors and market traders; raising chickens, ducks, and fishing; and service businesses such as workshops, workshops, and beauty salons are all examples of micro-businesses (Fatimah, 2018). Micro-enterprises are a possible business niche to represent in terms of banking interests to enhance their inter-mediation role. It is well understood that many micro-business actors continue to have trouble accessing banking credit services due to various challenges on both the small business and banking sides. The below are the profiles of micro-businesses that have been connected to financial institutions: Employees that employ one to five employees, including family members (Widjadja et al., 2018).

Small businesses are an integral part of the national business world, which has an important position, potential, and role in realizing national development goals. The criteria for small businesses are the Law of the Republic of Indonesia No. 20 of 2008 concerning micro, small and medium enterprises (Abhyankar, 2014; Martin et al., 2016; Maurer \& Li, 2006). Small businesses do not have a bookkeeping system, which causes entrepreneurs to switch from small businesses to bookkeeping. Small business is also a business activity in expanding employment opportunities and providing comprehensive economic services to accelerate economic distribution and income for the community-definition of Small Business According to the law. Small companies are commercial companies that are profitable autonomously carried out by individuals, according to Law Number 21 of the Republic of Indonesia (Storey et al., 2016). Small Businesses are particularly vulnerable if their new product does not sell or if one of their markets is hit by a recession. Small businesses cannot afford the enormous salaries and provide the opportunities and status that large corporations usually have. Small business owners must concentrate on the day-to-day business problems and usually have little time to think about long-term goals or plans. Large companies with many business fields may experience problems in one of their businesses, but they are still strong. The human presence factor is a significant force in facing small business competition (Ruggie, 2013).

Small business owners are the secret to their success and are more inspired. Companies cannot buy raw materials, equipment, or services as quickly as big businesses can, and they cannot get bulk discounts as big manufacturers can (Okkonen \& Suhonen, 2010). Any time they introduce a new product or reach a new market, they must uphold their image. People consider large-company goods because their brands are wellknown and often trusted. It is difficult to demonstrate any time a new market opportunity arises. Small companies have a significant comparative edge in terms of diversity. Proxy wars, antitrust actions, and federal controls are all persistent threats too large corporations (Gourevitch \& Shinn, 2010).

Arief, A. S., Pattiasina, P. J., \& Remus, S. P. (2021). Relevance of human resource management on small business objective in digital era: A critical review of research evidence. International Journal of Social Sciences and Humanities, 5(2), 79-91. https://doi.org/10.29332/ijssh.v5n2.1167 
In a small business, all issues are apparent, and decisions must be made immediately to address them. Small businesses that meet the following criteria will thrive: Meet needs unique to a small region (Hammond et al., 2015). Scenarios in which demand fluctuates a lot. Relevant consumer segments should be targeted. Avoid going head-to-head with colossal corporations. Provide logistical assistance. Provide individualized service provide facilities such as personal contact, maintenance service, or engineering assistance to add a personal touch. Customers can get personalized support. Customer care, engineering assistance, and customer service are also examples of providing a human touch to consumers (Jasmand et al., 2012).

\section{Business skills}

Management expertise To run a profitable business, an entrepreneur needs a wide range of abilities. Since any company is different, these capabilities change from one to the next (Wagner, 2010). Many companies need a set of skills and experience that are universal. Entrepreneurs must create a business plan, choose a form of ownership, and devise a marketing strategy. It is critical to understand where they can get the funds it will need to start and run the company (DeCenzo et al., 2016). The secret to success is good management, and owners must know when to obtain legal counsel, among other items. An entrepreneur's ability to adapt what he or she has learned demonstrates their level of expertise (Jones et al., 2015). Please click /impact and join us on Facebook and Twitter to help com's market coverage in the United States. Through reliable and up-to-date data, small business owners may determine the actual worth of their company. Reading and reviewing financial records is one of the responsibilities of financial management. Small business owners sometimes give customers credit to prevent them from switching to a competitor. Small business owners should stop over-indebtedness from paying off unpaid debts to avoid holding cash and collecting costs. It is essential to employ sound sales standards to retain new buyers and maintain existing ones (Osterwalder et al., 2014).

\section{Small businesses}

Medium-sized businesses are financially self-sufficient and sustainable (Farida et al., 2020). According to the Law of the Republic of Indonesia Number 20 of 2008 concerning Micro, Small and Medium Enterprises, medium-sized companies must have cash capital of more than IDR 500 million up to a total of IDR 1 billion as a barrier building for company premises. Almost all kinds of medium-sized companies, maybe equally, operate on goods from almost all industries. The goal of MSMEs development is to grow them into more prominent, more strategic business organizations that can help and enable micro, small, and medium-sized businesses to export (MSMEs). MSMEs have several strengths and disadvantages, including a lack of resources, a labor shortage, and difficulties in hiring workers (Ariani \& Utomo, 2017). Government programs, sponsors, nongovernmental organizations, proper infrastructure, democratic security, and equal and clean law enforcement must be endorsed.

It says the aim is to increase the number of entrepreneurs and the realization of increasingly resilient and independent businesses so that economic actors can play a role in the national economy. The goal is to make the country more competitive in the world markets. Kraja \& Osmani (2013), said the country needs to take steps to foster small, medium, and micro-businesses to make it more competitive with other countries. Most micro and small businesses have grown traditionally and are family businesses passed down from generation to generation. The limited human resources of these businesses greatly influence the management of their business (Dagenais et al., 2008; Feigin et al., 2003; Ng et al., 2017). It is challenging to adopt new technological developments to increase the competitiveness of the products it produces.

Because of a lack of evidence associated with the drivers in research and engineering, the market climate has not entirely adopted the government's approach to promoting and expanding miniature SMEs. As a result, their offices and systems have not proliferated and have not supported their business growth. According to Sahban \& SE (2018), SMEs' growth is essentially a shared responsibility of the federal and local governments. This issue is often misused as a deterrent by developed countries. As a result, SMEs must prepare ahead to be able to perform equally and in deregulation. Certain types of businesses, mainly traditional types of financially fragile businesses, need assurance from public authorities (Dwiyanto, 2018). The government is preparing to improve SMEs' market, administration, organization, and knowledge and skills to advance their businesses. To take an unconventional stance, they would have an agency responsible for planning all of the activities 
associated with small business growth. The aim is to solve MSMES's internal and external problems. The study also calls for systemic reform, which is typically beneficial to SMEs and large corporations (Hakim, 2019).

\section{Materials and Methods}

So, to see how HR created according to the needs of small companies in achieving their primary goals. As a method, we have reviewed hundreds of papers to find this significance by updating the papers we found electronically using Google scholar info. We focus on papers written between 2010 and 2021 to ensure that we have the most recent information. We use a phenomenological approach to interpret the data to find answers to this research problem. We also use labeling, analysis, and assessment methods to find out the correct, valid, and consistent data results. We follow the design of qualitative experts who discuss review studies on HR and SMEs.

\section{Results and Discussions}

This section of the author describes the findings of the analysis of ten previous research evidence papers that discuss the relevance of HR governance and efforts to achieve the goals of SMEs in the digital era. So the findings of Lal (2015), who examined how to transform HR in the advanced period through workforce investigation, can move individuals experts to the focal point of dynamic. This paper shows how the labor force examination can help human asset (HR) the board experts succeed in the advanced period. Features how examination can fit the ideal individuals to the correct positions, guarantee they get the correct preparation and the correct compensation, and stay faithful to the association. Draws on the creator's experience, in addition to a survey of the writing, was actual proof. The force of investigation can be utilized to make all HR capacities more powerful.

The following studies on that issue were from Dahlbom et al. (2019), who researched the vast information and HR examination in the advanced period. This examination gives and conjectures explorative information on HRA inside a gathering of probably the most prominent Finnish organizations. The outcomes show that both specialized and human deterrents, working with exceptionally essential HR measures and customary data frameworks and helpless information quality, upset the reception of cutting-edge HRA. The HRA use and job progress of the HR work appear to be firmly related, and this change can be commonly supporting. Moreover, social change and hierarchical upgrade might be called for and conquering innovative deterrents identified with BD to affect HR rehearses. The examination was distributed in the online version of the European human resource research diary.

The following proof of relevance comes from the study of Poisat \& Mey (2017). They examine the electronic, human resource of leaders in improving or attracting results. This article provides an assessment of the current level of development of various data related to the electronic human resources of the e-HRM board, which can improve advanced capabilities and impact employment (HR) as a fundamental partner. Further investigations are expected to understand the effects of e-HRM on progressive benefits and growing measures to see this effect. This article proposes additions to research and prove. This provides another convergence point for looking at e-HMurM checks while keeping it within view HR appraisal limits. It also provides an immense amount of experience on how assessments can be moved closer together.

Likewise, Kooij et al. (2013), executed human resource leaders to seek specific findings. More than twenty years of extensive review, which at this point cannot meet the demand for focus on the relationship between human resources and the board of directors and implementation. This is primarily credited to the limited proportion of investigations of a longitudinal nature. It sets different problems for the future on speculation, the leader cycle, and investigative theory.

Further, Saha et al. (2017), discussed authoritative agility and HRM methodologies asking whether they increase firm intensity? HR engineering empowers associations or companies to understand interior and external client values, information about competitors, items, innovations, and sources of excellence. Business accomplishments are built on the belief that an association achieves excellence by making acceptable and

Arief, A. S., Pattiasina, P. J., \& Remus, S. P. (2021). Relevance of human resource management on small business objective in digital era: A critical review of research evidence. International Journal of Social Sciences and Humanities, 5(2), 79-91. https://doi.org/10.29332/ijssh.v5n2.1167 
effective use of its relatives. This investigation demonstrates the importance of hierarchical readiness and the adequacy of human assets with an impact on increasing authoritative exercise and severe capacity.

Meanwhile, the findings of Stavrou et al. (2010), on how to board human resources and corporate execution in Europe from a business systems perspective: best fit, best practice, or both? This study uses the convergence point of Business Systems speculation to explore the meaning of the geographic setting on the relationship between human resources leadership and superior execution. The results raised concerns about the inevitable appropriateness of investigating HRM implementation and having ideas for standardizing HRM approaches and practices.

The issue of similarity between HR governance and the achievement of SMEs goals was also evidenced by Garavan \& McGuire (2010), where they examined the progress of human and community assets. Division of increasing human resources in instilling corporate social, management, and moral obligations in the association. The progressive advancement of human assets (HRD) is expected to participate in CSR, support, and morale in the association. He has been criticized for moving from his primary goal of advocating humanistic qualities to thoroughly accepting a fleeting business plan. This article follows a set of activities that HRD can use to change the orientation of the setting, consider affiliation reliable, give the organization CSR and ethics, and ensure that affiliation is profitable and robust.

Furthermore, Jiang et al. (2012), also prove how the board's human resources affect the various outcomes leveled? A meta-shrewd study of intermediate frameworks has proven how this meta-assessment examines the effect of three HR system segments on legitimate outcomes. The results show that capacity-building practices are more closely related to HR and more minor to specialist motivation. All three estimates are related to financial results, either directly or indirectly. Why relies on the limit-motivated opportunity model.

Jackson et al., (2014), studied optimistic systems for executives' vital human assets. A vital area of human assets, executives, have long and rich habits. We audited and studied HRM hypotheses and explorations that were vital for thirty years. They energize new explorations that accept framework thinking, which more fully addresses the concerns of different partners. We are centered on the value of the HRM framework as an organizational tool for influencing a wide variety of outcome concerns to internal and external partners.

Proof of the relationship between HR and SMEs performance comes from Agyapong (2010). He discusses how miniature, small and medium business practice, salary levels, and poverty reduction in ghana-A related mixed writings. This paper audits the paper on the importance of MSMEs for monetary turnover and poverty mitigation. It is prescribed to governments and policymakers to arrange appropriate credit support and nonmonetary business support administration to assist the development of MSMEs. The paper says independent businesses play an essential part in creating jobs, adding to costs, fees, import revenues, working with product circulation, and supporting business and development. It arranges for the government to assist private companies through credit support.

\section{Conclusion}

We can conclude that this review has succeeded in answering the question of this study which asks the relationship between HR governance and efforts to promote small businesses in many business execution contexts. Dozens of studies have analyzed, on average, linking that there is a vein relationship between efforts to build human resources to achieve the core goals of every business, namely profit and sustainability. Proving a quality human resource management relationship will undoubtedly help SMEs achieve their goals. So we can add that improving HR governance is a continuous effort made to help develop quality staff and personnel owned by small businesses with a variety of skills, work skills, and loyalty to a company, both small and large of the organization. If quality HR governance is, of course, it will be easy for companies to develop and achieve the core goals of SMEs.

\section{Acknowledgments}

We, the authors, arrange thousands of thanks to all parties, colleagues, and university supervisors, and editors for their support and feedback so that this paper has been well done. Likewise, our respectful greetings to the Ministry of Research and Technology for their assistance. Because without their support, all of this paper entitled "Relevance of Human Resource Management on Small Business Objective in Digital Era: A Critical Review of Research Evidence" would not be finished. 


\section{References}

Abhyankar, R. (2014). The government of India's role in promoting innovation through policy initiatives for entrepreneurship development. Technology Innovation Management Review, 4(8).

Agyapong, D. (2010). Micro, small and medium enterprises' activities, income level and poverty reduction in ghana-A synthesis of related literature. International Journal of Business and Management, 5(12), 196.

Apriyani, F. (2014). Analisis Efisiensi Pemasaran Bawang Merah Dalam Upaya Peningkatan Pendapatan Usahatani (Studi Kasus di Desa Karangsemi, Kecamatan Gondang, Kabupaten Nganjuk). [PhD Thesis]. Universitas Brawijaya.

Ardiana, I., Brahmayanti, I. A., \& Subaedi, S. (2010). Kompetensi SDM UKM dan pengaruhnya terhadap kinerja UKM di Surabaya. Jurnal Manajemen Dan Kewirausahaan, 12(1), pp-42.

Ariani, A., \& Utomo, M. N. (2017). Kajian strategi pengembangan usaha mikro kecil dan menengah (UMKM) di kota tarakan. Jurnal Organisasi Dan Manajemen, 13(2), 99-118.

Bratton, J., \& Gold, J. (2017). Human resource management: Theory and practice. Palgrave.

Caliendo, M., \& Kritikos, A. S. (2010). Start-ups by the unemployed: Characteristics, survival and direct employment effects. Small Business Economics, 35(1), 71-92.

Charoenrat, T., \& Harvie, C. (2014). The efficiency of SMEs in Thai manufacturing: A stochastic frontier analysis. Economic Modelling, 43, 372-393.

Dagenais, S., Caro, J., \& Haldeman, S. (2008). A systematic review of low back pain cost of illness studies in the United States and internationally. The spine journal, 8(1), 8-20. https://doi.org/10.1016/j.spinee.2007.10.005

Dahlbom, P., Siikanen, N., Sajasalo, P., \& Jarvenpää, M. (2019). Big data and HR analytics in the digital era. Baltic Journal of Management.

DeCenzo, D. A., Robbins, S. P., \& Verhulst, S. L. (2016). Fundamentals of human resource management. John Wiley \& Sons.

Del Brìo, J. A., \& Junquera, B. (2003). A review of the literature on environmental innovation management in SMEs: implications for public policies. Technovation, 23(12), 939-948. https://doi.org/10.1016/S01664972(02)00036-6

Dharmanegara, I. B. A., Sitiari, N. W., \& Wirayudha, I. (2016). Job competency and work environment: The effect on job satisfaction and job performance among SMEs worker. IOSR Journal of Business and Management (IOSR-JBM), 18(1), 19-26.

Dwiyanto, A. (2018). Manajemen Pelayanan Publik: Peduli Inklusif Dan Kolaborasi. UGM PRESS.

Ellis, T. (2010). The New Pioneers: Sustainable business success through social innovation and social entrepreneurship. John Wiley \& Sons.

Farida, S. I., Prasetiyani, D., Safiih, A. R., Prasada, D., \& Ismanto, B. (2020). Pelatihan SDM: Usaha Konvensional menjadi Usaha Digital. Jurnal Abdi Masyarakat Humanis, 1(2).

Fatimah, F. (2018). Strategi Kreatif UMKM Kerajinan Tangan Di Era Digital Pada Wilayah Kabupaten Jember. PROSIDING EKONOMI KREATIF DI ERA DIGITAL, 1(1).

Feigin, V. L., Lawes, C. M., Bennett, D. A., \& Anderson, C. S. (2003). Stroke epidemiology: a review of populationbased studies of incidence, prevalence, and case-fatality in the late 20th century. The lancet neurology, 2(1), 43-53. https://doi.org/10.1016/S1474-4422(03)00266-7

From, J. (2017). Pedagogical Digital Competence-Between Values, Knowledge and Skills. Higher Education Studies, 7(2), 43-50.

Garavan, T. N., \& McGuire, D. (2010). Human resource development and society: Human resource development's role in embedding corporate social responsibility, sustainability, and ethics in organizations. Advances in Developing Human Resources, 12(5), 487-507.

Glaub, M. E., Frese, M., Fischer, S., \& Hoppe, M. (2014). Increasing personal initiative in small business managers or owners leads to entrepreneurial success: A theory-based controlled randomized field intervention for evidence-basedmanagement. Academy of Management Learning \& Education, 13(3), 354379.

Gourevitch, P. A., \& Shinn, J. (2010). Political power and corporate control. Princeton University Press.

Hakim, M. K. (2019). Peran pembiayaan KUR terhadap perkembangan UMKM masyarakat muslim di Kabupaten Kudus: Study kasus Bank BRI Syariah Cabang Kudus [PhD Thesis]. UIN Walisongo.

Arief, A. S., Pattiasina, P. J., \& Remus, S. P. (2021). Relevance of human resource management on small business objective in digital era: A critical review of research evidence. International Journal of Social Sciences and 
Hammond, J. S., Keeney, R. L., \& Raiffa, H. (2015). Smart choices: A practical guide to making better decisions. Harvard Business Review Press.

Hifza, Juliana, Palapa, A., Maskur, \& Aslan. (2020). The Strategic Foundation for Competitive Excellent Development in Integrated Islamic Primary Schools in Indonesia. International Journal of Advanced Science and Technology, 29(12s), 1747-1753.

Hutagaluh, O. \& Aslan. (2019). Pemimpin dan Pengaruh Geo Politik Terhadap Lahirnya Sumber Daya Manusia Yang Berkarakter. Jurnal Studi Islam Lintas Negara, 1(2), 23-29.

Hutagaluh, O., Aslan, Putra, P., Syakhrani, A. W., \& Mulyono, S. (2020). SITUATIONAL LEADERSHIP ON ISLAMIC EDUCATION. IJGIE : International Journal of Graduate of Islamic Education, 1(1), 1-7.

Jackson, S. E., Schuler, R. S., \& Jiang, K. (2014). An aspirational framework for strategic human resource management. Academy of Management Annals, 8(1), 1-56.

Jasmand, C., Blazevic, V., \& De Ruyter, K. (2012). Generating sales while providing service: A study of customer service representatives' ambidextrous behavior. Journal of Marketing, 76(1), 20-37.

Jiang, K., Lepak, D. P., Hu, J., \& Baer, J. C. (2012). How does human resource management influence organizational outcomes? A meta-analytic investigation of mediating mechanisms. Academy of Management Journal, 55(6), 1264-1294.

Jones, N., Borgman, R., \& Ulusoy, E. (2015). Impact of social media on small businesses. Journal of Small Business and Enterprise Development.

Kehoe, R. R., \& Wright, P. M. (2013). The impact of high-performance human resource practices on employees' attitudes and behaviors. Journal of Management, 39(2), 366-391.

Komalasari, I., Choeriyah, S., Jamaludin, E., \& Kamal, I. (2019). ANALISIS PERBEDAAN KINERJA KEUANGAN DAN KEPUASAN BEKERJA SEBELUM DAN SESUDAH MENGGUNAKAN APLIKASI KEUANGAN TERPUSAT. Jurnal Ekonomi Dan Bisnis Terapan, 15(1), 73-106.

Kooij, D. T., Guest, D. E., Clinton, M., Knight, T., Jansen, P. G., \& Dikkers, J. S. (2013). How the impact of HR practices on employee well-being and performance changes with age. Human Resource Management Journal, 23(1), 18-35.

Kraja, Y., \& Osmani, E. (2013). Competitive advantage and its impact in small and medium enterprises (SMEs)(Case of Albania). European Scientific Journal, 9(16).

Lal, P. (2015). Transforming HR in the digital era: Workforce analytics can move people specialists to the center of decision-making. Human Resource Management International Digest.

Martin, G., Farndale, E., Paauwe, J., \& Stiles, P. G. (2016). Corporate governance and strategic human resource management: Four archetypes and proposals for a new approach to corporate sustainability. European Management Journal, 34(1), 22-35. https://doi.org/10.1016/j.emj.2016.01.002

Maurer, S. D., \& Li, S. (2006). Understanding expatriate manager performance: Effects of governance environments on work relationships in relation-based economies. Human Resource Management Review, 16(1), 29-46. https://doi.org/10.1016/j.hrmr.2006.02.001

Ng, S. C., Shi, H. Y., Hamidi, N., Underwood, F. E., Tang, W., Benchimol, E. I., ... \& Kaplan, G. G. (2017). Worldwide incidence and prevalence of inflammatory bowel disease in the 21st century: a systematic review of population-based studies. The Lancet,390(10114), 2769-2778. https://doi.org/10.1016/S01406736(17)32448-0

Nicholls, J. G. (2017). Conceptions of ability and achievement motivation: A theory and its implications for education. In Learning and motivation in the classroom (pp. 211-238). Routledge.

Noe, R. A., Hollenbeck, J. R., Gerhart, B., \& Wright, P. M. (2017). Human resource management: Gaining a competitive advantage. McGraw-Hill Education New York, NY.

Nurani, N., Nurjanah, R., \& Prihantoro, I. (2020). COMPETENCE OF HUMAN RESOURCES OF SMALL AND MEDIUM ENTERPRISES (MSMES) OF WEST JAVA THROUGH INTELLECTUAL PROPERTY RIGHTS (IPR) PROTECTION IN THE COVID-19 PANDEMIC ERA. PalArch's Journal of Archaeology of Egypt/Egyptology, 17(10), 3878-3896.

Nurani, N., Nurjanah, R., \& Prihantoro, I. (2021). Competence of Human Resources of Small and Medium Enterprises (MSMEs) of West Java through Intellectual Property Rights (IPR) Protection in the COVID-19 Pandemic Era. Psychology and Education Journal, 58(3), 251-264.

Okkonen, L., \& Suhonen, N. (2010). Business models of heat entrepreneurship in Finland. Energy Policy, 38(7), 3443-3452. 
Osterwalder, A., Pigneur, Y., Bernarda, G., \& Smith, A. (2014). Value proposition design: How to create products and services customers want. John Wiley \& Sons.

Poisat, P., \& Mey, M. R. (2017). Electronic human resource management: Enhancing or entrancing? SA Journal of Human Resource Management, 15(1), 1-9.

Randolph, R. V., Alexander, B. N., Debicki, B. J., \& Zajkowski, R. (2019). Untangling non-economic objectives in family \& non-family SMEs: A goal systems approach. Journal of Business Research, 98, 317-327. https://doi.org/10.1016/j.jbusres.2019.02.017

Reed, H. E., \& Mberu, B. U. (2014). Capitalizing on Nigeria's demographic dividend: Reaping the benefits and diminishing the burdens. Etude de La Population Africaine= African Population Studies, 27(2), 319.

Riniwati, H. (2016). Manajemen Sumberdaya Manusia: Aktivitas Utama dan Pengembangan SDM. Universitas Brawijaya Press.

Robb, A. M., \& Robinson, D. T. (2014). The capital structure decisions of new firms. The Review of Financial Studies, 27(1), 153-179.

Ruggie, J. G. (2013). Just business: Multinational corporations and human rights (Norton global ethics series). WW Norton \& Company.

Saha, N., Gregar, A., \& Sáha, P. (2017). Organizational agility and HRM strategy: Do they really enhance firms' competitiveness? International Journal of Organizational Leadership, 6, 323-334.

Sahban, M. A., \& SE, M. (2018). Kolaborasi Pembangunan Ekonomi di Negara Berkembang (Vol. 1). Sah Media.

Samsuni, S. (2017). Manajemen sumber daya manusia. Al-Falah: Jurnal Ilmiah Keislaman Dan Kemasyarakatan, 17(1), 113-124.

Schunk, D. H. (2012). Learning theories an educational perspective sixth edition. Pearson.

Sedyastuti, K., Suwarni, E., Rahadi, D. R., \& Handayani, M. A. (2021). Human Resources Competency at Micro, Small and Medium Enterprises in Palembang Songket Industry. 2nd Annual Conference on Social Science and Humanities (ANCOSH 2020), 248-251.

Stavrou, E. T., Brewster, C., \& Charalambous, C. (2010). Human resource management and firm performance in Europe through the lens of business systems: Best fit, best practice or both? The International Journal of Human Resource Management, 21(7), 933-962.

Storey, D. J., Keasey, K., Watson, R., \& Wynarczyk, P. (2016). The performance of small firms: Profits, jobs and failures. Routledge.

Sudarmo, Nugraha, M. S., MARDHIAH, R. I.liow, F. E., \& ASLAN. (2021). The Identification of Online Strategy Learning Results While Students Learn from Home During the Disruption of the COVID-19 Pandemic in Indonesia. Journal of Contemporary Issues in Business and Government, 27(2), 1950-1956. https://doi.org/10.47750/cibg.2021.27.02.205

Suharti, L., Sugiono, L., \& Purwati, Y. (2013). Model Adopsi Inovasi Teknologi Pada Umk Tempe: Studi Pada Pengrajin Tempe Anggota Kopti Di Kotamadya Salatiga Dan Kabupaten Boyolali, Jawa Tengah. Sustainable Competitive Advantage (SCA), 3(1).

Thaha, A. F. (2020). Dampak covid-19 terhadap UMKM di Indonesia. BRAND Jurnal Ilmiah Manajemen Pemasaran, 2(1), 147-153.

Toby, A. J., \& Peterside, D. B. (2014). Analysis of the role of banks in financing the agriculture and manufacturing sectors in Nigeria. International Journal of Research in Business Management, 2(2), 9-22.

Wagner, T. (2010). The global achievement gap: Why even our best schools don't teach the new survival skills our children need-and what we can do about it. ReadHowYouWant. com.

Wang, Q., Hang, Y., Sun, L., \& Zhao, Z. (2016). Two-stage innovation efficiency of new energy enterprises in China: A non-radial DEA approach. Technological Forecasting and Social Change, 112, 254-261.

Widiastuti, E., \& Martini, S. (2016). Kompetensi SDM Dan Pengaruhnya Terhadap Kinerja UMKM Batik Di Kabupaten Banyumas. Performance, 23(2).

Widjadja, Y. R., Alamsyah, D. P., Rohaeni, H., \& Sukanjie, B. (2018). Peranan Kompetensi SDM UMKM Dalam Meningkatkan Kinerja UMKM Desa Cilayung Kecamatan Jatinangor, Sumedang. Jurnal Abdimas BSI: Jurnal Pengabdian Kepada Masyarakat, 1(3).

WIJAKSONO, H. P., SUGIARTO, Y., \& IDRIS, I. (2014). Analisis orientasi kewirausahaan dan sumber daya internal perusahaan terhadap kinerja melalui keunggulan bersaing (Studi pada Usaha Mikro Kecil dan Menengah Furniture Kabupaten Jepara) [PhD Thesis]. Diponegoro University.

Arief, A. S., Pattiasina, P. J., \& Remus, S. P. (2021). Relevance of human resource management on small business objective in digital era: A critical review of research evidence. International Journal of Social Sciences and

Humanities, 5(2), 79-91. https://doi.org/10.29332/ijssh.v5n2.1167 
Wisenthige, K., \& Guoping, C. (2016). Firm level competitiveness of small and medium enterprises (SMEs): analytical framework based on pillars of competitiveness model. International research journal of management, IT and social sciences, 3(9), 61-67.

Wulansari, N. A., Ranihusna, D., \& Maftukhah, I. (2015). Strategi Perencanaan SDM untuk Peningkatan Daya Saing UMKM Batik Semarang.

Yacob, P., Wong, L. S., \& Khor, S. C. (2019). An empirical investigation of green initiatives and environmental sustainability for manufacturing SMEs. Journal of Manufacturing Technology Management.

Yang, L., Wang, J., \& Shi, J. (2017). Can China meet its 2020 economic growth and carbon emissions reduction targets? Journal of Cleaner Production, 142, 993-1001.

Yusuf, B., \& Al Arif, M. N. R. (2015). Manajemen sumber daya manusia di lembaga keuangan syariah. Rajawali Pers. 


\section{Biography of Authors}

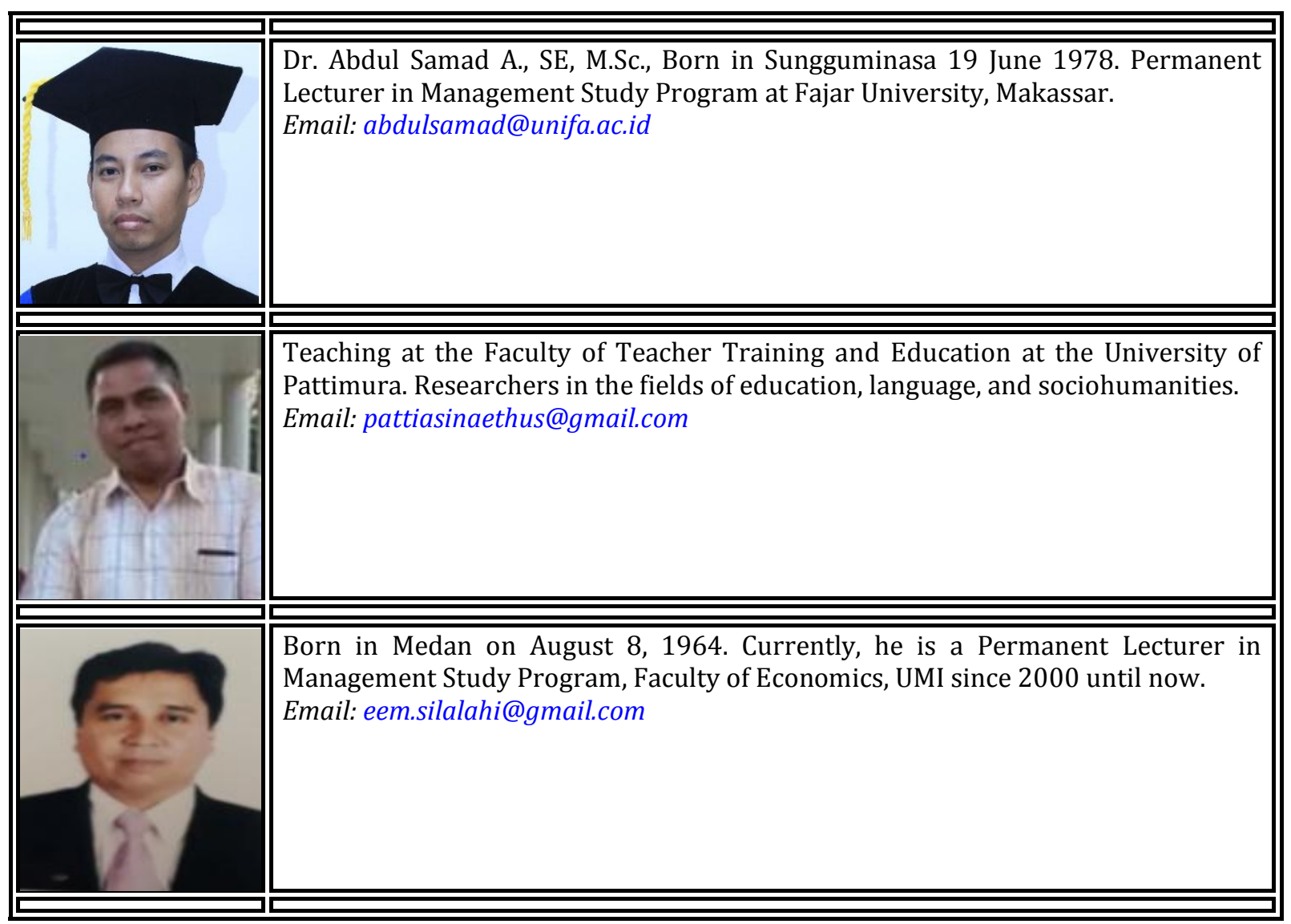

Arief, A. S., Pattiasina, P. J., \& Remus, S. P. (2021). Relevance of human resource management on small business objective in digital era: A critical review of research evidence. International Journal of Social Sciences and Humanities, 5(2), 79-91. https://doi.org/10.29332/ijssh.v5n2.1167 